\title{
Algal Biomass to Bio-Energy: Recent Advances
}

\author{
Suresh Kumar* \\ Department of Zoology, CRM Jat (P. G.) College, Hisar - 125001, Haryana, India; suresh_sang@yahoo.co
}

\begin{abstract}
The crops, grasses, trees, algae and cyano-bacteria in the presence of sun perform photosynthesis and store chemical energy in a wide range of feed stocks such as starch, sugars and lipids that can be used for the production of biofuels. The crop plants such as sugar cane, oil palm, sugar beet, rapeseed soyabeans, wheat and corn are extensively used for the production of biofuels such as ethanol, diesel and methane. Due to increasing world population and extensive droughts in major regions pressure on food supplies has resulted in growing concern and has led to a heated food versus fuel debate. Biofuel systems that do not require arable land is developed and these include lingo cellulosic processes which convert cellulose-based products from plants into liquid fuels. Myscanthus, Camelina, Switchgrass, Sorghum, and Poplar trees are some of good source of biofuel at present. The success of these systems is depend on research and development of energy-efficient manufacturing processes, typically enzymatic lignin digestion processes, although chemical digestion methods are also under investigation. Due to demand for large amounts of enzyme appears to be as mountable challenge, ultimately this technology might also contribute to food versus fuel concerns because of its dependence on forest. This in turn could lead to a forest versus fuel issue, unless waste products from agricultural and forestry systems are exclusively used, or feed stocks produced on non-arable land can be developed. Although these crops can be grown on non-arable land, their productivity remains linked to soil fertility and water supply, and the scale of cultivation required to make a meaningful contribution towards global energy consumption will inevitably require lands that are currently used for food production or forestry. Many micro algae can be grown in saline water and are able to produce a wide range of feed stocks for the production of biofuels, including biodiesel, methane, ethanol, butanol and hydrogen, based on their efficient production of starch, sugars and oils.
\end{abstract}

Keywords: Algae, Biofuel, Enzyme, Popular, Sorghum, Starch, Waste

\section{Introduction}

The world economy requires fossil fuel to providing energy for transportation, mining, lighting and daily uses. The demand of energy is increasing continuously because of increases in population, industry and modern amenities. The main sources of energy are petrol, diesel, CNG, coal, hydro and nuclear power ${ }^{2}$. The fossils fuels cause environmental pollution, greenhouse gases and air contaminants including NOx, SOx, CO, particulate matter and volatile organic compounds ${ }^{3}$. As many countries improve their gross domestic product per capita, their fossil fuel use will increase and competition for these limited resources will increase. Petrol and diesel, is derived from ancient algae deposits, is a limited resource that will run out or become too expensive to regenerate ${ }^{2-4}$. These factors are driving the development of renewable energy sources that can supplement fossil fuels and allow greater access to fuel resources for all nations. Many technologies have been developed as renewable energy sources and although no single strategy is likely to provide a solution, it seems possible that a combination of technologies can be employed that will substantially decrease our dependence on fossil fuels ${ }^{4}$. The challenge that remains is to develop renewable energy industries that operate sustainably and can be cost competitive with existing energy options.

Fossil fuels are used for the production of petrol, diesel, kerosene and electricity. There are many technologies that can generate electricity, including solar, wind, hydroelectric, geothermal and nuclear. However, renewable technologies to replace fossil fuels are still in their initial developmental stages. Increasing energy demand, environmental pollution, climate change and carbon dioxide $\left(\mathrm{CO}_{2}\right)$ emission from fossil fuels make it a high priority to search for low environment pollution. The most sustainable alternate of fossil fuels are biofuels. It plays an important role in our energy security. It is considered as potentially cheap, low pollution source. Generally, ethanol made

*Author for correspondence 
from sugarcane reduces greenhouse gases, replacing gasoline. So, biofuels have been explored as a possible alternative source to gasoline. The total biofuel production tripled from 2002 to 2009, but still accounts for less than $3 \%$ of the global transportation fuel supply. The uses of biofuels are increasing day by day due to (i) Reduced dependence on fossil fuels (ii) Decrease in greenhouse gas emission (iii) Country independent security of fuel supply (iv) Employment and economic benefits through the development of a new fuel production. The International Energy Agency expects that biofuels will contribute 6\% of total fuel use by 2030. Most biofuels currently used are obtained from land crops, including sugar cane, maize and vegetable oil. These are known as "first-generation" biofuels. These biofuels have come under criticism for competing with food production for land and water resources, motivating the search for alternatives. These include "second generation" biofuels from wood, wastes, grasses and agricultural residues and biofuels from algae. The regional success of some of these strategies is well noted; in particular, the sugarcane-toethanol production in Brazil ${ }^{5}$. To a lesser degree, oils from terrestrial plants - for example, soy and palm - are used to produce biodiesel. These technologies are functional at the small scale; however, as their use has increased, it is evident that they are not sustainable, owing to the enormous amount of agricultural land that would be required to supplement a significant fraction of petroleum using this strategy ${ }^{6,7}$. Many hybrid strategies are currently being used. Examples of such strategies include conversion of cellulose to sugars for fermentation into fuel, and gasification of residual biomass into gas that can be used to produce liquid fuels ${ }^{8}$. Although each of these strategies is being used to produce fuels, they are insufficient to accommodate the world demand for liquid fuels. With the decrease of fossil-based fuels and the environmental impact of them over the planet, it seems necessary to seek the sustainable sources of clean energy. Biofuel is becoming a global leader in the development of renewable energy resources. It is necessary to say that algal biofuel production is thought to help stabilize the concentration of carbon dioxide in the atmosphere and decrease global warming impacts. Algal biodiesel is non-polluting, with no sulfur, highly biodegradable and relatively harmless to the environment if spilled. Algae are capable of producing in excess of 50 times more oil per acre than corn and soybean crops. At present, algal biofuel production has not been commercialized due to high costs associated with production, harvesting and oil extraction but the technology is progressing. Now day's extensive research is conducted to determine the utilization of microalgae biomass as a source of energy and oil production commercially. Bioenergy is one of the most important components to mitigate greenhouse gas emissions and alternate of fossil fuels ${ }^{1}$. Large-scale introduction of biomass energy could contribute to sustainable development on environmentally, socially and economic ${ }^{4}$. Biodiesel is one alternative fuel, which is obtained by the transesterification of triglyceride oil with monohydric alcohols. It has been well-known that biodiesel obtained from canola and soybean, palm, sunflower oil, algal oil as a diesel fuel substitute $^{5,6}$. Biodiesel fuel can be prepared from waste cooking oil, palm, soybean, canola, rice bran, sunflower, coconut, corn oil, fish oil, chicken fat and lgae $^{7}$ which would partly decrease the dependency on petrol and diesel based fuel. Biomass has been focused on as an alternative energy source, since it is a renewable resource and it fixes $\mathrm{CO}_{2}$ in the atmosphere through photosynthesis. Among biomass, algae usually have a higher photosynthetic efficiency than other biomass ${ }^{10}$. In fact, algae are the highest yielding feedstock for biodiesel. It can produce up to 250 times the amount of oil per acre as soybeans. The best algae for biodiesel would be microalgae. Microalgae are an organism capable of photosynthesis that is less than 2 $\mathrm{mm}$ in diameter. Macroalgae, like seaweed, is not as widely used in the production of biodiesel which has much more oil than macroalgae and it is much faster and easier to grow $^{10}$. It can provide several different types of renewable biofuels like methane produced by anaerobic digestion of the algal biomass ${ }^{6}$ biodiesel derived from microalgal oil ${ }^{11-13}$ and photobiologically produced biohydrogen ${ }^{14,15}$. Crude oil from algae will likely be an important energy feedstock of the future. Algal oil could be made into diesel, gasoline and jet fuel, and become a renewable feedstock for making plastics and the other chemicals that are now obtained from petroleum at great cost to the environment ${ }^{1,6}$. Displacing petroleum derived transport fuels with fuels from algae could potentially reduce emission of carbon dioxide by roughly $30 \%$ in the United States.

Algal cultivation can be carried out using nonarable land and non-potable water with simple nutrient supply. Its production is higher than those of vascular plants and the extractable content of lipids that can be usefully converted to biodiesel. Algae oil identified as a reliable resource for biodiesel production due to its high lipid productivity and potential cultivation in non-fertile locations. 


\section{Uses of Biofuels}

\subsection{Biofuels Use in Transportation}

Many countries have set a goal for $10 \%$ of the energy used in road and rail transport to be obtained from renewable sources by 2020 . Around $2.4 \%$ of the surface transport energy was obtained from biofuels in England in 2009 and the committee on climate change forecast that biofuels could provide a $7 \%$ reduction in $\mathrm{CO}_{2}$ emissions from surface transport by 2020 . After all biofuels produce lowcarbon and renewable options for surface transport include hydrogen fuel cells and electric vehicles.

\subsection{Biofuels Use in Aviation Industry}

Air transport is expected to continue to depend upon liquid fuels, because electrification and fuel cells are considered unsuitable in air. Airplane produced high emission of $\mathrm{CO}_{2}$ and greenhouse gases by using of fossil fuel. Which encourage the use of alternative fuels. So, aviation sector is increasingly interested in biofuels as "drop-in" replacements for fossil fuel. Some in the aviation industry believe that biofuels should be reserved for air travel, given the absence of alternatives for the sector. The International Air Transport Association (IATA) states that $6 \%$ of aviation fuel could be obtained from renewable sources by 2020. In 2011 the international standards body ASTM International approved a standard for aviation biofuels, allowing biofuels to be used in commercial flights.

\subsection{Biofuels Use as Biodiesel and Hydrocarbon}

Algae contain over $80 \%$ total lipids, while rapeseed plants, for instance, contain about $6 \%$ lipids, which lead more production of biodiesel. Botryococcus, algae do not produce lipids, but longer chain hydrocarbons, which are not suitable for biodiesel production. Instead, they can be converted in a process similar to the production of conventional fuels from fossil oil.

\subsection{Biofuel Use in Ethanol Production}

Ethanol is commonly produced from starch-containing feedstock. Algae also have been reported to contain over $50 \%$ of starch. Algal cell walls consist of polysaccharides which can be used in ethanol production, with the added advantage that algae rarely contain lignin and their polysaccharides, are generally more easily broken down than woody biomass.

\subsection{Biofuel Use in Biogas Production}

Organic material can be converted into biogas that contains about $60 \%-70 \%$ bio methane, while the rest is mainly $\mathrm{CO}_{2}$, which can be fed back to the algae. Second, advantage is that the nutrients contained in the digested biomass can be recovered from the liquid and solid phase. Biogas production, as well as other conversion processes, is not viable to date because of the current high cost of the feedstock, although it is currently one of the cheapest biofuel that can be produced from biomass.

\subsection{Production of Hydrogen}

Algae can be converted into hydrogen gas. The cost of this process is low and since no energy is lost by the cells to form hydrogen, not much biomass is produced and therefore there is little potential for co-production.

\subsection{Production of Bioelectricity}

Algal biomass can use in power plant to produce energy. This purpose the biomass needs to be dried, which implies a significant amount of energy.

\subsection{Advantages of Algae Biomass as Biofuel}

- Biofuels and byproducts can be produced from a large variety of algae.

- Algae have a good growth rate.

- Algae can be cultivated in freshwater, brackish coastal water and seawater.

- Land areas which are unsuitable for agriculture can be used to cultivate algae.

- Algae can be using a good source of high nitrogen, silicon, phosphate, and sulfate nutrients.

- Algae biomass can absorb carbon dioxide from industrial sources.

\subsection{Algal Bioenergy Co-production}

Integrated food and energy can be produced from algae thus increase the simultaneous production of food and energy through sustainable land management. The specific production of energy and other co-products such as food, feed and biochemical from algae obtain in two ways. 


\subsection{Algal Bioenergy Co-production}

Algal products can be used in many ways such as healthfood, cattle feed and feed for aquaculture. If the entire biomass is consumed, there is no leftover for bioenergy production. There is however the option to design cultivation systems that co-produce algae, seaweed, fish or shellfish, thereby providing possible feedstock for bioenergy. Many of the algal products, especially those used for food, such as proteins, omega-3-fatty acids and some carbohydrates cannot be subjected to high temperatures.

\subsection{Future Scope of Algae Biofuel}

The biofuel production from algae involves the different stages such as growth, concentration, separation and conversion of microalgae biomass. After separation the desired biofuel product from the microalgae biomass, a significant portion of byproduct left. The remaining byproducts have a very useful for the economic and environmental sustainability. By using bacteria, mold and yeast a desired by product ethanol can be produce. As a sustainable source of energy, algae and the feed stocks have great capacity to meet the demands of replacing petrol diesel-based fuels. Now, biotechnology develops, and the algae industry is focused on producing high-value products such as pharmaceutical, nutritional supplements and biofuel production at low, competitive prices, as well as byproducts such as the protein for distiller's grains and carbohydrates for ethanol. Algal biofuel will directly affect the transportation fuels such as biodiesel, ethanol, petroleum and it will also impact on many environmental and economic resources by treatment of wastewater, capture of carbon dioxide from power plants, production of human and animal food, pharmaceuticals, cosmetics, and organic fertilizers; aquaculture, and soil nutrient recovery. Ultimately, the need to decrease fossil fuel dependence makes it necessary that algae and algae-derived products are safe to humans and the environment. The rapid commercial expansion of the algae biofuels industry is an excellent example of sustainable product development with dramatic future potential for contributions to fuel supplies, yet many questions regarding algae production remain unanswered.

Today, the waste products that are discharged into the environment as contaminants will be utilized to produce much needed renewable energy sources. Now is the time to initiate the development of an algae industry evaluation that allows for the advancement of knowledge and tools.

\subsection{Production of Bioenergy and Economic Viability}

Algal production has a strong influence on the economics of the process, as it determines how much product the cultivation system produces. If the market price of the product is known, the money available for producing the algae and extracting the products can be calculated. Actual estimates for dry microalgal biomass yield vary from 40 to 80 tons per year per hectare depending on the technology used and the site of production. The site of the production system is also important for the economics, as it determines the costs of land, labour, $\mathrm{CO}_{2}$, nutrients supply and other factors that have a major influence on the process. At present microalgae production is based on relatively small systems, producing high value products for special niche markets. Because of these high value products, the market price of microalgae is on the average $€ 250 / \mathrm{kg}$ dry biomass, which is 1000 times too high for producing biofuel, if the algae have a $50 \%$ oil content. Biomass prices between $€ 0.5$ and $€ 5 / \mathrm{kg}$ are regularly calculated for large systems. For biofuel, the technology needs to develop from a small-scale activity to an industrial scale technology. During this development, production costs will decrease and with every step-in reduction, new markets will open. Most likely, initially the production of edible oils for food and fish feed will become economically viable and only later the production of bulk chemicals, biomaterials and biofuels can become feasible. By assessing the viability of algae projects from a market perspective, it is clear that total installation, operation and maintenance costs will be a major barrier to future commercialization but technologies are being developed to further reduce costs and increase yields.

\subsection{Algae Oil Extraction}

1. Single-Step Extraction: The Single-Step oil extraction process is simpler and more efficient than other systems, due to no requirement of chemicals and heavy machinery. The single step process harvests concentrates and extracts oil from algae and separates oil, water and biomass in one step in less than an hour. The company's Quantum Fracturing technology combines with electromagnetic pulses and $\mathrm{pH}$ modification to break down cell walls and release oil from the algae cells.

2. Continuous Algal Oil Extraction System: Cavitation Technologies Inc. (CTI) has developed a technology 


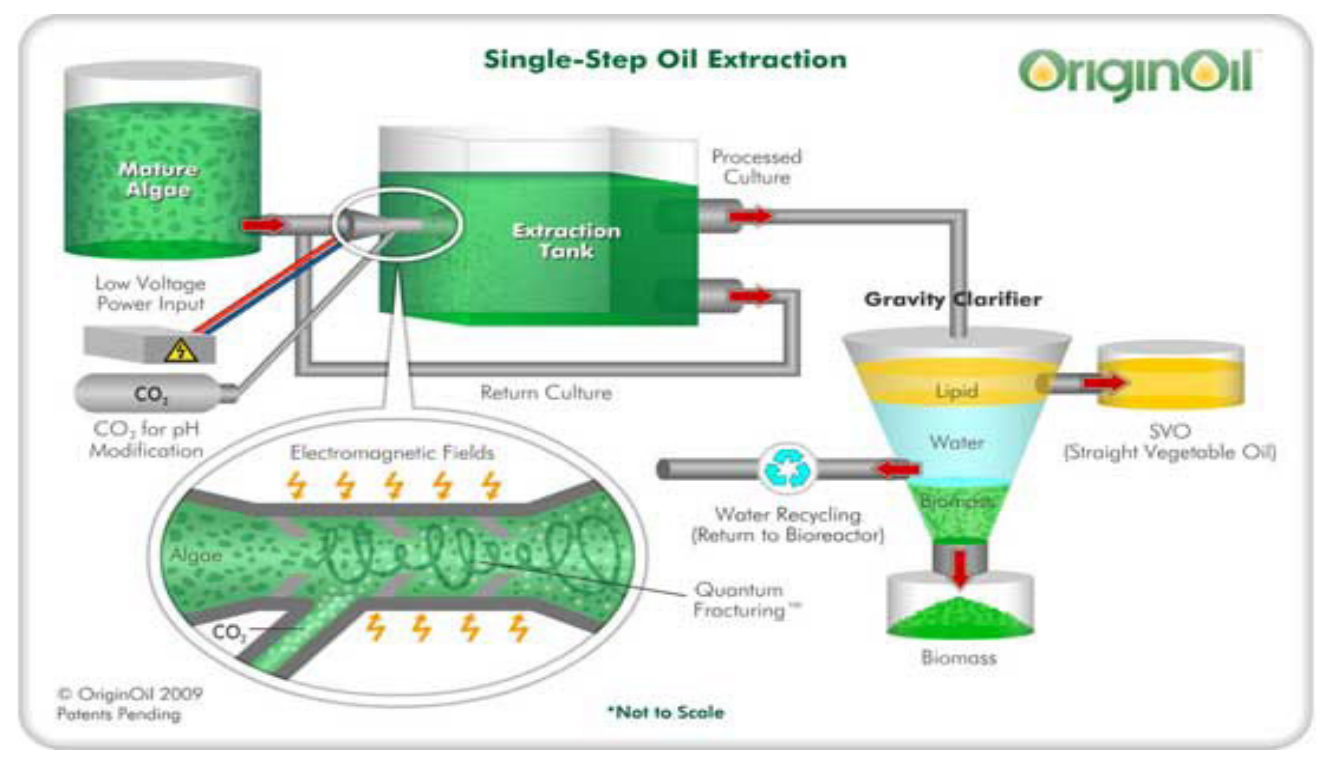

Single-Step Algal Oil Extraction.

that is able to extract oil from algae on a continuous basis utilizing cavitation-based extraction. CTI's Nano reactor is used to create cavitation bubbles in a solvent material, when these bubbles collapse near the cell walls it creates shock waves and liquid jets that causes those cells walls to break and release their contents into the solvent. The company plans to license the technology to algal fuel developers.

3. Extraction Using Nano- Technology: National Alliance for Advanced Biofuels and Bioproducts (NAABB), developed pioneering algal oil extraction technology using mesoporous nanoparticles to selectively extract and sequester targeted fuel-relevant and high value compounds within the algal lipid mixture. The balance of the algal oil, which contains free fatty acids and triglycerides, will be converted to biodiesel using Catilin's commercially available T300 catalyst. This technology is efficient and solid catalyst provides a cost-effective conversion route.

\subsection{Algal Biofuel: Importance and Challenges}

There are various challenges to making biofuels for competing with petroleum. Certainly, a low price is guarantee for clean fuels (fuels that have a 50\% lower $\mathrm{CO}_{2}$ cradle-to-grave footprint than petroleum); however, estimated costs of a barrel of algae-based fuel using current technology is US $\$ 300-2600$, compared with $\$ 40-80$
(2009) for petroleum ${ }^{9-12}$. Although some estimates for a barrel of algae oil in specific regions reach as low as $\$ 84^{13}$. The higher dollar estimates are more common and similar to our own estimates and exclude algal oil from the current liquid fuel market.

\subsection{Benefits of Algal Biofuels}

Algae can produce biomass very rapidly, with some species doubling in as few as $6 \mathrm{~h}$ and many exhibiting two doublings per day ${ }^{16,17}$. All algae have the capacity to produce energy-rich oils and a number of microalgal species have been found to naturally accumulate high oil levels in total dry biomass ${ }^{18}$. The microalgae groups such as diatoms, green algae, golden brown, prymnesiophytes, eustigmatophytes and cyanobacteria ${ }^{16}$, and members from all of these groups have been examined as potential fuel production strains. Algae have a reduced impact on the environment compared with terrestrial sources of biomass used for biofuels. They can be grown on land that would not be used for traditional agricultural and are very efficient at removing nutrients from water. Thus, not only would production of algae biofuels minimize land use compared with biofuels produced from terrestrial plants but in the process of culturing these microalgae, waste streams can be remediated. Potential waste streams include municipal wastewater to remove nitrates and phosphates before discharge and flue gas of coal or other combustible-based power plants to capture sulfates and $\mathrm{CO}_{2}^{22-24}$. Algae production strains also have the potential 
to be bioengineered, allowing improvement of specific traits ${ }^{25,26}$ and production of valuable co-products, which may allow algal biofuels to compete economically with petroleum. These characteristics make algae a platform with a high potential to produce cost-competitive biofuels.

\subsection{Challenges for Algal Fuel Commercialization}

The high growth rates, reasonable growth densities and high oil contents have all been consider as investing significant capital to turn algae into biofuels. However, for algae to mature as an economically viable platform to offset petroleum and, consequently, mitigate $\mathrm{CO}_{2}$ release, there are a number of hurdles to overcome ranging from how and where to grow these algae, to improving oil extraction and fuel processing.

\subsection{Future Perspective of Biofuel}

Algae-based fuels are needed to be costs competitive with petroleum. It is important to identify algae species that have high lipid content, growth rates, growth densities and the presence of valuable co-products, while growing on lowcost media. The genetic engineering and breeding will be required to bring these strains to economic viability. The range of potential for engineering algae is just beginning to be realized, from improving lipid biogenesis and improving crop protection, to producing valuable enzyme or protein co-products. No sustainable technology is without its challenges but blind promotion of those technologies without honest consideration of the long-term implications may lead to the acceptance of strategies whose long-term consequences outweigh their short-term benefits. We have presented what we view as the most important current and upcoming challenges of algae biofuels but, as with any new industry, the more we learn the more we realize that challenges exist that we had not foreseen. Even given these uncertainties, we believe that fuel production from algae can be cost competitive and widely scalable and deployable in the next 7-10 years, but only if we continue to expand our understanding of these amazing organisms as we expand our ability to engineer them for the specific task of developing a new energy industry.

\section{Overview of Biofuel}

The crops, grasses, trees, algae and cyano-bacteria in the presence of sun perform photosynthesis and store chemical energy in a wide range of feed stocks such as starch, sugars and lipids that can be used for the production of biofuels. The crop plants such as sugar cane, oil palm, sugar beet, rapeseed soyabeans, wheat and corn are extensively used for the production of biofuels such as ethanol, diesel and methane. Due to increasing world population and extensive droughts in major regions pressure on food supplies has resulted in growing concern and has led to a heated food versus fuel debate ${ }^{15}$. Biofuel systems that do not require arable land is developed and these include lingo cellulosic processes which convert cellulose-based products from plants into liquid fuels. Myscanthus, Camelina, Switchgrass, Sorghum, and Poplar trees are some of good source of biofuel at present. The success of these systems is depending on research and development of energy-efficient manufacturing processes, typically enzymatic lignin digestion processes, although chemical digestion methods are also under investigation. Due to demand for large amounts of enzyme appears to be as mountable challenge, ultimately this technology might also contribute to food versus fuel concerns because of its dependence on forest. This in turn could lead to a forest versus fuel issue ${ }^{19}$, unless waste products from agricultural and forestry systems are exclusively used, or feed stocks produced on nonarable land can be developed. Although these crops can be grown on non-arable land, their productivity remains linked to soil fertility and water supply, and the scale of cultivation required to make a meaningful contribution towards global energy consumption will inevitably require lands that are currently used for food production or forestry. Micro-algal biofuel systems Micro-algal biofuel systems, which produce fuels from single-celled microalgae (eukaryotes or cyanobacteria) have the advantage that their productivity is not dependent on soil fertility, and thus could theoretically be scaled to make a substantial contribution to global demand without increasing the pressure on arable land or important forest ecosystems. Many micro algae can be grown in saline water and are able to produce a wide range of feed stocks for the production of biofuels, including biodiesel, methane, ethanol, butanol and hydrogen, based on their efficient production of starch, sugars and oils ${ }^{20,21}$. Because they absorb $\mathrm{CO}_{2}$ from both atmospheric and (in some cases) industrial sources during growth, micro algae can also contribute to carbon capture. Carbon storage can theoretically then be achieved by pyrolysing the waste biomass remaining after fuel production to produce a charcoal-like product (Biochar) suitable for long-terms 
to rage ${ }^{22}$. Bio-char canal so be used as a fuel in its own right, reducing dependency on coal, or marketed as a soil additive ${ }^{23}$. However, although micro algal biofuel systems can 'in theory' eliminate both the food versus fuel and potential forest versus fuel problems, to date no microalgal biofuel systems have achieved economic viability. At present we need to develop a new technology to process the algae for the extraction of biofuels.

\section{References}

1. Parry ML. Intergovernmental panel on climate change, working group II, World Meteorological Organization, United Nations Environment Programme. Summary for Policymakers. In: Parry ML, Canziani OF, Palutikof JP, van der Linden PJ, Hanson CE. Climate Change 2007: Impacts, Adaptation and Vulnerability Contribution of Working Group II to the Fourth Assessment Report of the Intergovernmental Panel on Climate Change. Cambridge University Press; Cambridge, UK; 2007.

2. Dyni JR. Scientific Investigations Report 2005-5294. US Geological Survey; VA, USA: 2006. Geology and resources of some world oil-shale deposits. https://doi.org/10.3133/ sir29955294.

3. Schindler J, Zittel W. Crude oil - the supply outlook. Vol. 102. Energy Watch Group; Ottobrunn, Germany; 2008.

4. Energy Information Administration. International Energy Outlook. Vol. 284. EIA; DC, USA; 2009.

5. Nass LL, Pereira PAA, Ellis D. Biofuels in Brazil: an overview. Crop Science. 2007; 47:2228-37. https://doi. org/10.2135/cropsci2007.03.0166.

6. Fargione J, Hill J, Tilman D, Polasky S, Hawthorne P. Land clearing and the biofuel carbon debt. Science.2008;319(5867):1235-1238. Promotes looking at the impact of biofuels total lifecycle analysis, and redefines what should be looked at in that analysis. https://doi. org/10.1126/science.1152747.

7. Searchinger T, Heimlich R, Houghton RA, et al. Use of U.S. croplands for biofuels increases greenhouse gases through emissions from land-use change. Science. 2008; 319(5867):1238-40. https://doi.org/10.1126/ science. 1151861 .

8. Huber GW, Iborra S, Corma A. Synthesis of transportation fuels from biomass: chemistry, catalysts, and engineering. Chemical Reviews. 2006; 106(9):4044-98. https://doi. org/10.1021/cr068360d.

9. Dismukes GC, Carrieri D, Bennette N, Ananyev GM, Posewitz MC. Aquatic phototrophs: Efficient alternatives to land-based crops for biofuels. Current Opinion in Biotechnology. 2008; 19(3):235-40. https://doi. org/10.1016/j.copbio.2008.05.007.
10. Borowitzka MA. Algal biotechnology products and processes - matching science and economics. Journal of Applied Phycology. 1992; 4:267-79. https://doi. org/10.1007/BF02161212.

11. Chisti Y. Biodiesel from microalgae. Biotechnology Advances. 2007; 25(3):294-306. https://doi.org/10.1016/j. biotechadv.2007.02.001.

12. Alabi AO, Tampier M, Bibeau E. Microalgae technogies and processes for biofuels/bioenergy production in British Columbia. The BC Innovation Council; BC, Canada; 2009.

13. Huntley ME, Redalje DG. $\mathrm{CO}_{2}$ mitigation and renewable oil from photosynthetic microbes: A new appraisal. Mitigat Adapt Strategies Global Change. 2006; 12:573-608. https:// doi.org/10.1007/s11027-006-7304-1.

14. Falkowski PG, Barber RT, Smetacek VV. Biogeochemical controls and feedbacks on ocean primary production. Science. 1998; 281(5374):200-7. https://doi.org/10.1126/ science.281.5374.200.

15. Parker MS, Mock T, Armbrust EV. Genomic insights into marine microalgae. Annual Review of Genetics. 2008; 42:619-45. https://doi.org/10.1146/annurev. genet.42.110807.091417.

16. Sheehan J, Dunahay T, Benemann J, Roessler P. A look back at the u s department of energy's aquatic species program - biodiesel from algae. Vol. 328. National Renewable Energy Laboratory; CO, USA; 1998. https://doi. org/10.2172/15003040.

17. Huesemann MH, Hausmann TS, Bartha R, Aksoy M, Weissman JC, Benemann JR. Biomass productivities in wild type and pigment mutant of Cyclotella sp. (diatom). Applied Biochemistry and Biotechnology. 2009; 157(3):507-26. https://doi.org/10.1007/s12010-008-8298-9.

18. Rodolfi L, Chini Zittelli G, Bassi N, et al. Microalgae for oil: strain selection, induction of lipid synthesis and outdoor mass cultivation in a low-cost photobioreactor. Biotechnology and Bioengineering. 2009; 102(1):100-12. https://doi.org/10.1002/bit.22033.

19. Kojima E, Zhang K. Growth and hydrocarbon production of microalga Botryococcus braunii in bubble column photobioreactors. Journal of Bioscience and Bioengineering. 1999; 87(6):811-15. https://doi. org/10.1016/S1389-1723(99)80158-3.

20. Deschamps P, Moreira D. Signal conflicts in the phylogeny of the primary photosynthetic eukaryotes. Molecular Biology and Evolution. 2009; 26(12):2745-53. https://doi. org/10.1093/molbev/msp189.

21. Reeb VC, Peglar MT, Yoon HS, et al. Interrelationships of chromalveolates within a broadly sampled tree of photosynthetic protists. Molecular Phylogenetics and Evolution. 2009; 53(1):202-11. https://doi.org/10.1016/j. ympev.2009.04.012. 
22. He P, Xu S, Zhang H, et al. Bioremediation efficiency in the removal of dissolved inorganic nutrients by the red seaweed, Porphyra yezoensis, cultivated in the open sea. Water Research. 2008; 42(4-5):1281-9. https://doi.org/10.1016/j. watres.2007.09.023.

23. Fierro S, Sanchez-Saavedra Mdel P, Copalcua C. Nitrate and phosphate removal by chitosan immobilized Scenedesmus. Bioresource Technology. 2008; 99(5):12749. https://doi.org/10.1016/j.biortech.2007.02.043.

24. Douskova I, Doucha J, Livansky K, et al. Simultaneous flue gas bioremediation and reduction of microalgal biomass production costs. Applied Microbiology and Biotechnology. 2009; 82(1): 179-85. https://doi.org/10.1007/s00253-0081811-9.
25. Rosenberg JN, Oyler GA, Wilkinson L, Betenbaugh MJ. A green light for engineered algae: Redirecting metabolism to fuel a biotechnology revolution. Current Opinion in Biotechnology. 2008; 19(5):430-6. https://doi. org/10.1016/j.copbio.2008.07.008.

26. Zaslavskaia LA, Lippmeier JC, Shih C, Ehrhardt D, Grossman AR, Apt KE. Trophic conversion of an obligate photoautotrophic organism through metabolic engineering. Science. 2001; 292(5524):2073-5. https://doi.org/10.1126/ science.160015.

27. Lehr F, Posten C. Closed photo-bioreactors as tools for biofuel production. Current Opinion in Biotechnology. 2009; 20(3):280-5. https://doi.org/10.1016/j.copbio.2009.04.004. 